\title{
(息)
}

Citation:

Stanley, L and Dampier, H (2013) 'I Just Express My Views \& Leave Them to Work': Olive Schreiner as a Feminist Protagonist in a Masculine Political Landscape with Figures. 157 - 180. DOI: https://doi.org/10.1111/j.1468-0424.2012.01701.x

Link to Leeds Beckett Repository record:

https://eprints.leedsbeckett.ac.uk/id/eprint/540/

Document Version:

Article (Accepted Version)

The aim of the Leeds Beckett Repository is to provide open access to our research, as required by funder policies and permitted by publishers and copyright law.

The Leeds Beckett repository holds a wide range of publications, each of which has been checked for copyright and the relevant embargo period has been applied by the Research Services team.

We operate on a standard take-down policy. If you are the author or publisher of an output and you would like it removed from the repository, please contact us and we will investigate on a case-by-case basis.

Each thesis in the repository has been cleared where necessary by the author for third party copyright. If you would like a thesis to be removed from the repository or believe there is an issue with copyright, please contact us on openaccess@leedsbeckett.ac.uk and we will investigate on a case-by-case basis. 


\section{'I Just Express My Views \& Leave Them to Work': Olive Schreiner as a Feminist Protagonist in a Masculine Political Landscape with Figures}

\section{Liz Stanley and Helen Dampier}

I have written two long letters to my brother. I don't argue with him: I just express my views \& leave them to work. That's the best way with him. ${ }^{1}$

\section{Introduction}

Gender history as we see it is a multifaceted body of ideas and research held together by recognising disturbances as well as regularities in the gender order, and it includes exploration of challenges to and reworkings of conventional gender hierarchies. An example of such reworking is the focus of discussion here: the political interventions of South African feminist writer and social theorist Olive Schreiner (1855-1920) and the influence of these activities. ${ }^{2}$ Schreiner left colonial South Africa for Britain in 1881. When she returned in late 1889 she had become one of the world's most famous women, author of the international best-selling novel The Story of An African Farm, followed by publication of allegories on ethical and political topics which captured public attention worldwide. ${ }^{3}$ She also started publishing social commentary on political and economic matters, and before returning to Africa had conceived a major project, to investigate South African society and its racial and political divisions in a series of essays to be published pseudonymously as, 'A Returned South African'. When the first essay appeared in 1891, the author's identity became known and Schreiner was quickly established as a major radical social commentator on South African matters. South Africa at the time was on the world stage as the epicentre of imperialist and capitalist expansion and central to the 'scramble for Africa' by the competing imperialist autocracies, one of the reasons Schreiner's commentaries achieved such high profile.

The Schreiner Letters Project has transcribed and published the complete nearly 4,800 surviving Olive Schreiner letters located in archival locations worldwide and is also analysing these in research-based publications. ${ }^{4}$ The attention here is on Schreiner's letters to her brother Will (William Philip) Schreiner, Attorney-General 
and then later Prime Minister of the Cape Colony (part of what later became South Africa) at a crucial period of its history; to the so-called Cape liberal politicians John Xavier Merriman and Francois Stephanus Malan, who were Will's close colleagues; and to less close ones such as the Afrikaner Bond leader Jan Hofmeyr. ${ }^{5}$ Discussion of these letters is organised around exploration of important epistemological questions. How can Schreiner's political influence within the masculine political landscape of the Cape Colony in the late-nineteenth and early-twentieth centuries be gauged? Did she shape or change any of the tumultuous events which occurred there? Can her letters provide compelling evidence of her political influence on the white masculine political landscape of the Cape? And if so, what import does this have for understanding the gender order more widely? Examined here in relation to Schreiner's presence in a masculine political landscape, such epistemological questions also exercise historiography more generally. With what certainty can knowledge claims about the past be advanced? Can cause and effect be demonstrated between influence being exerted and behaviour or events being changed? And if it can, then what is appropriate and sufficient evidence to convincingly show this?

We explore these questions in the context of feminist historiography's concern with gender, and in particular 'separate spheres'. The idea of separate spheres has importantly influenced how the lives of women and men in late-nineteenth-century Europe and elsewhere have been conceived and how the dynamics of the gender order are understood. ${ }^{6}$ They have also proved contentious because of often not readily fitting specific times, places and persons. ${ }^{7}$ As Lynn Abrams aptly comments,

the tension [exists] between the grand narrative of modern European women's history and the micro-study of a particular place and experience. Adopting a perspective far removed from the metropolitan heart of Europe forces one to think differently about the prime motors of change and the chronology of that change ... an alternative history can only emerge from a historical practice which privileges a social memory crafted around narratives of women whose sense of the past included themselves. ${ }^{8}$

We agree with this need for an alternative history conceived away from the 'metropolitan heart', and the particular woman whose narratives we explore in this way is Olive Schreiner. In doing so, we also recognise the complexities of separate spheres in practice in the context we are dealing with, which is the white enclave states of the Cape, Natal, Transvaal and Orange Free State, which later in 1910 united to form the Union of South Africa.

On one level, white enclave South Africa before and during Schreiner's lifetime embodied gendered and raced separate spheres in the many raced and gendered separations which configured its social and political life. ${ }^{9}$ On another, the period's racialised social structures and practices were both constituted and dismantled daily in practical ways by black people increasingly being treated in de-humanised ways as labouring 'hands', initially concerning men living and working in diamond and gold mining compounds and later affecting women and men who worked in domestic and related services. ${ }^{10}$ For black people, the racial practices that constituted 'separate spheres' formed a harsh disciplining reality, but at the same time these were also routinely and mundanely breached as services and labour were required, organised and carried out on a daily basis. The result was that for whites, gendered separate spheres were in 
some contexts (particularly among the urban educated elite) maintained in an exaggerated form, enabled through reliance on black labour carrying out activities which white lower-class women would have done elsewhere, while in other contexts (the farm, frontier or widowhood in both) women might take on many 'male' activities and roles. Both the disciplining and this complicated breaching have to be acknowledged analytically, and the implications for understanding the interface of gender and racial hierarchies in the context reckoned with in historical scholarship.

In the European and North American context, gender historians have recognised that separate spheres were traversed, if not overturned, in family and kinship contexts and in semi-private ones in civil society, in part because women provided an array of necessary labour for public sphere organisations and activities. That is, in practice gendered separate spheres were modulated and often conjoined, particularly at everyday and familial levels. However, this both translates and does not, in interesting ways, to the South African context. In the white enclave communities of South Africa, from Schreiner's childhood to her middle adulthood, there was an attenuated civil society largely bereft of the many groups and organisations characterising European societies. ${ }^{11}$ The colonial political sphere of the Cape (and also of the independent Boer settler states of the Transvaal and Orange Free State and the British colony of Natal) was male, small-scale, sequestered and widely seen as corrupt, with the remit of its government contained and constrained by the British imperial presence via its Governor and the military, legal and bureaucratic apparatus he commanded. The Cape's political sphere was also largely separated from the thriving 'private' sphere centring on family and kinship mapped mainly onto land and agricultural production of various kinds, with later enclave industrial production occurring around mining in diamonds and gold. Of course material complexities coexisted with the simplicities of separate spheres ideology: as noted above, by no means all white women lived entirely confined lives. The circumstances of frontier and farming life militated against this, for women routinely managed significant aspects of agricultural production and trading, and often oversaw large groups of household and other servants. ${ }^{12}$

But at the same time, the bounded character of this breaching is notable. There was only a narrow set of possibilities, largely resulting from the occluded presence of black labour of all kinds. That is, the actual daily presence and labour of black people was combined with notions of separation, for they were routinely involved in carrying out work as nursemaids, herdsmen, field-hands, domestic workers and many more occupations. But also, in spite of these complex daily realities, the impact of ethnic/racial separate spheres thinking both limited the kinds of work seen as appropriate for white women, and relatedly it provided an 'other' which was viewed in ethnic and then increasingly in racial terms as threatening and dangerous and so requiring white women's sequestration from it, which lent a particular flavour to the dynamics and interrelationships of gendered separate spheres in the southern African context. $^{13}$

Schreiner, then, grew up in the complexly configured, highly gendered and raced context of a white colonial enclave which was dependent upon routine servicing from black people's labour. Succinctly, in practice separate spheres overlapped and were interrelated in colonial South Africa and the enclave was actually surrounded, underpinned and supported by the black majority. ${ }^{14}$ She left in 1881 to live in Britain and elsewhere in Europe, returning to South Africa in late 1889. In the period away, she 
published The Story of an African Farm. ${ }^{15}$ Its immense international success propelled her and her subsequent publications, including many shorter allegorical writings, into the glare of public attention. At this time, her friends and acquaintances included some of the 'great and the good' and the liberal intelligentsia of British political and cultural life, including William Gladstone, his daughter Mary Gladstone Drew, Charles Dilke, Emilia Dilke, Robert Browning, George Moore, Helen Taylor, Oscar Wilde, Keir Hardie, Frank Harris and W. T. Stead, as well as the reformers she is more commonly associated with, including Eleanor Marx, Edward Carpenter and Havelock Ellis, among many others. Schreiner became a much lionised public figure whose ideas and opinions were taken seriously as one of the world's most famous women and she was seen to be on a par with international male public figures such as the imperialist entrepreneur and politician Cecil Rhodes.

When Schreiner first returned to South Africa in late 1889, a sense of palpable shock comes across in her letters concerning the slow pace of life in the white enclave and the narrowness of white people's lives and opinions, describing them as a nation of 'Philistines' with no aristocracy of 'blood or intellect or of muscular labourers'. ${ }^{16}$ She immediately started work on her 'A Returned South African' essays. ${ }^{17}$ Schreiner had conceived these as a 'project' before she left Britain, writing to the editor and journalist Stead in such terms. ${ }^{18}$ She presented them as an epistemological endeavour concerned with what she described in the first essay as two forms of knowledge, of insiders and outsiders, which competed with each other in making claims to know about a country. ${ }^{19}$ These essays are concerned with the particular mixture of races and ethnicities characterising South Africa and addressed to a complicated 'home', composed of reading audiences in the imperial metropole, the white enclave populations of colonial South Africa, as well as a wider international audience. Schreiner's writing went hand in hand with her close involvement in the social aspects of Cape white enclave political life, which centred on events around the short parliamentary session in Cape Town. This was quickly followed by her critique of the policies and practices of Rhodes as Cape Prime Minister as well as head of De Beers diamonds and also a major presence in the gold industry, and also her critique of the Cape's liberal politicians and their failure to provide an effective opposition to Rhodes and his followers. She became, as our subtitle states, a feminist protagonist in this highly masculine political landscape, with its background figures being those of other white women and of the black population. Following her 1889 return to the Cape, Schreiner developed allegiances with like-minded South Africans, including women's organisations during the South African War and feminist networks thereafter and also members of the burgeoning black intelligentsia. These alliances lasted through to her departure for Britain at the end of 1913. She then remained in Britain until her final return to Africa in mid-1920, and over this latter period, in addition to her close connections with international feminist and pacifist individuals and groups, Schreiner also established close connections with members of various black delegations which arrived in London to lobby the imperial parliament. ${ }^{20}$

Although Schreiner developed demonstrably friendly links with key black political figures of the time, including John Tengo Jabavu, Solomon Plaatje, John Dube, A. K. Soga, Abdullah Abdurahman and Mohandas Gandhi among others, this cordial relationship paradoxically led to few letters being exchanged between her and them. 
This is because, apart from the people Schreiner was personally very close to, her correspondents were people she actively disagreed with and her letters were an important means by which she sought to change their minds and political behaviours. Few Schreiner letters to these black leaders exist as a consequence, because she and they agreed on most political matters. There is in fact just one letter initiating a friendship with Abdurahman and one letter rather sadly reminding Gandhi of his pacifist principles, although the many mentions of an array of black leaders in her letters to other people show contacts with them to have been extensive. This points to just how focused Schreiner's exhortatory letters were on divisive political topics, particularly race matters. ${ }^{21}$ And from this follows our attention to her letter writing to the so-called Cape liberal politicians, including her brother, for though there was much disagreement between her and them, Schreiner's letters suggest she hoped she could influence them to behave in accordance with their stated political principles.

Previous political biographers and historians of South Africa amply recognised the influence of Schreiner's political analysis and strategising on Cape politicians and its political life more generally. ${ }^{22}$ However, the succeeding generation of scholars rejected the liberal stance of earlier works and instead focused around a Marxist analysis of race and labour in the context of apartheid South Africa. ${ }^{23}$ There were many gains; but the loss of knowledge of the earlier period of white radicalism ironically and unintentionally had the effect of reinforcing the distortions of apartheid knowledge making. Under apartheid, much work failed to 'see' both the early rapidly expanding black intelligentsia and bourgeoisie, and also the white radicalism on race matters that our discussion here is concerned with. ${ }^{24}$ However, the many rich sources in South African archives and a new generation of historiography engaging with such issues is helping recover this lost knowledge. ${ }^{25}$ Olive Schreiner moved in an international and national landscape and wrote many letters. In her case these sources are largely epistolary in character, with her letters located in archives outside, as well as within, the country. ${ }^{26}$ Among other things, her letters enable this period of white radicalism and the relationship with black political figures to be seen and its importance for understanding the South African past to be explored. ${ }^{27}$ Relatedly, Schreiner's letters analytically interrogate, inquire and argue with ideas concerning feminism, imperialism, capitalism, colonialism, questions of race and racism, the state, labour, the woman question, war and other topics. ${ }^{28}$ They also provide considerable information on her practical involvements and related writing projects. ${ }^{29}$ They are, then, a crucially important source material.

Letters are sometimes viewed as a disreputable data source because of their lack of direct referentiality and their inscription of dialogical, perspectival, emergent and serial aspects. ${ }^{30}$ However, no written sources escape their ontological status as mediated forms and all historical documents have such characteristics, not just letters. Consequently, the issues we raise about reading and interpreting epistolary sources are also relevant to other kinds of archival materials. In addition, letters allow scholars to explore the viewpoints of letter writers and their addressees over time, opening up for scrutiny an epistolary network such as Schreiner's, wherein letter writing was interspersed with other kinds of political activity. Olive Schreiner's letters are a particularly interesting and important resource in this regard: they are written by a key feminist theorist and social commentator; they span an especially momentous period of change between the 1870s and 1920 in terms of technologies of letter writing and major social 
issues of the time and subsequently; they engage analytically with the social and other changes occurring and consider where these would take society in the future; they were often written and used as politics, rather than just being about politics, and they provide tantalising hints about interconnections between white radicals and the black political and intellectual elite. ${ }^{31}$ Obviously the existence of political letters as a subgenre of letter writing is well known and has been the focus of some recent interesting discussions, which have considered the ways in which women have deployed letters as a means of circumventing the prohibitions and limitations imposed in more formal political contexts. ${ }^{32}$ In general, however, previous scholars have assumed the impact or otherwise of letter writing trends by referring to a range of circumstantial evidence, while our discussion moves beyond contentions of an 'it is likely' character, to explore how cause and effect might be pinned down.

In what follows, we consider in detail Schreiner's 'expressing my views and leaving them to work' strategy for gaining political influence, as commented on in the letter providing this article's epigraph. In doing so, we explore a number of instances where her influence is undoubted, but where it is, nonetheless, surprisingly difficult to demonstrate this with certainty, and from this we then consider how a more certain view of influence or its absence might be gained. As well as outside-the-text ways of thinking about exactly how influence can be demonstrated and proven, we shall also discuss ways of doing this which relate to letters themselves, because important textual demonstrations of influence can be found within her letters.

\section{Olive Schreiner's 'characteristic shrewdness' - Walker's case for influence}

Olive Schreiner's brother Will (1857-1919) was an important legal and political presence in South African public life, starting in 1887 with his appointment as legal advisor to the Cape Governor, until his death in 1919 while serving as High Commissioner in London. Eric Walker, a leading South African liberal historian who wrote the key political biography of Will Schreiner, treats Olive Schreiner's influence on her brother's political views and practices as a certain fact and provides several in-depth examples. ${ }^{33}$ Therefore, we start exploring influence and its proof by examining what Walker saw as certainties and the evidence he provided to substantiate them, because his work provides a strong case for seeing Schreiner as a feminist protagonist who had considerable influence and impact in this masculine political landscape.

Will Schreiner became legal advisor to Rhodes's De Beers Company and then Cape Attorney-General in 1893 when Rhodes became Prime Minister. When Will became Prime Minister in October 1898, he worked to heal the political breaches caused by the Jameson Raid (an 1895-6 plot in which Rhodes attempted to use force to annex the Transvaal - an independent Boer (later Afrikaner) republic). He also tried to thwart Imperial Governor Milner's and British Colonial Secretary Chamberlain's provocation of the South African War of 1899-1902 between Britain and the two Boer Republics of the Transvaal and Orange Free State. Later his thinking moved leftward: he headed the legal defence of the Zulu king, Dinuzulu, against trumped-up charges in 1907-8; he opposed the Union of the four settler states (the Boer republics and the British colonies of the Cape and Natal); he led a 1909 black delegation to Britain to lobby against the draft of the South Africa Act, which unified the four white settler 
states and from 1910 to 1914 he was a senator with the role of representing black views in the Union parliament's upper house. ${ }^{34}$

Over the period when Olive Schreiner published her political writings, women had no formal presence in South African political life; they were voteless in the settler states and then in the Union of South Africa in $1910 .{ }^{35}$ There was a strong local culture of gender conventions governing its formal political life, and within this, with just a few exceptions, the ways women gained informal influence through political salons and similar means in European and US contexts were largely absent. ${ }^{36}$ Olive Schreiner commented her brother had little political 'nose', no 'shrewdness', and he agreed. ${ }^{37}$ Schreiner had keenly developed and widely recognised, if not always welcomed, political skills, while Will's were minimal. But it was he who had the high profile public political career, while she forced her ideas into the public domain through high circulation writings like 'A Returned South African' and The Political Situation essays. Schreiner harnessed this fame to facilitate political connections, using women's proto-feminist networks to put pressure on 'the men' and also through letters which articulated analytical ideas and arguments and sought to influence the political views and behaviours of her addressees, as we explore later. Her letters to Will provide important evidence of her challenging and subverting prevailing separate spheres conventions. Letters by many of her correspondents, including Will Schreiner, John Merriman, F. S. Malan and Jan Smuts, also show that these men accepted her right and ability to dissent, even while often disagreeing with her.

Many passages in Walker's political biography of Will Schreiner emphasise Olive Schreiner's political shrewdness and her influence on her brother at important junctures in his political life. Walker had no doubt about this influence, stating for instance that 'If he went with Rhodes and the Bond, Schreiner knew that Olive would be grieved. And her grief would hurt him, since he had long regarded her as a kind of detached and most eloquent conscience reinforcing the still, small voice he always found so insistent. It was no light matter for him to go against her'. ${ }^{38}$ Comments like this very certain statement of Olive Schreiner's influence occur multiply in Walker's book and add up to something very compelling, but what proof is there of such claims?

One instance of Walker claiming her influence concerns the fact that in 1898, following Cape and British investigations of the Jameson Raid, a vote of no confidence in the Rhodes government was moved by Will Schreiner, who expected Jan Hofmeyr, leader of the Afrikaner Bond, to then become Prime Minister. Olive Schreiner, always with an eye on the political future, advised her brother that if a strong liberal bloc was to be formed, Will himself should lead it and that Hofmeyr would 'stand back' for this; Walker concludes '[Will] Schreiner settled accounts with his little demon [the still, small voice of conscience] and decided to go forward' ${ }^{39}$ Then in April 1899, in the run-up to the South African War and as Prime Minister of the Cape Colony, Will had to respond to the political difficulties of the Transvaal Republic, which was trapped between not wanting its political system overrun by uitlanders (outsiders), present largely in gold-mining and finance activities around the Rand gold mines, and British provocation of war by claiming the uitlanders were being denied political rights. Will had little sympathy for the uitlander protests, and Walker comments that 'Olive, with characteristic shrewdness, had noticed this lack in her brother's mental equipment' and advised him to 'deal direct' with the parties involved. ${ }^{40}$ 
Walker's conclusion is that 'Schreiner did not, indeed, could not go; so to the end he remained without first-hand knowledge', that is, he did not go to the Transvaal himself. ${ }^{41}$ However, years after Walker's biography was written, Will Schreiner's papers were donated to what is now the National Library of South Africa in Cape Town, which show that Will did deal directly with both sides, using trusted envoys. ${ }^{42}$ Walker, then, was incorrect; the Schreiner letters to Will which are now available (i.e. not just those Walker had access to) show the strength of her counsel to her brother and demonstrate that he did a volte-face in his attempts to prevent war, by moving in precisely the direction of her counsel. What does not exist, however, is evidence which directly links her counsel to his change, however likely her influence on him is. ${ }^{43}$

The second example concerns the July 1899 recall of General Butler, then commander of Britain's troops in South Africa, because he was too peace-loving. Before leaving, Butler wrote to Will Schreiner, still Prime Minister, to strongly support Will's political tactics of peacemaking. Even though Olive Schreiner was an outspoken, high profile public supporter of the Transvaal, Will sent Butler's letter to her, writing on its back his hope that the Transvaal could avoid being provoked into declaring war, probably a treasonous act were it to be known. ${ }^{44}$ As many of Schreiner's letters to Will during September 1899 show, they were fully in each other's political confidence, so sending her Butler's letter clearly demonstrates his trust in her discretion and desire for her counsel. ${ }^{45}$ In the larger political landscape, what followed these events was a major increase in political tension and then war, largely because of Milner's intransigence in forcing war on the Transvaal. Then, Walker writes, 'While [Will] was debating thus [about resigning] he received a letter from Olive. "Ultimately", she wrote, "we have nothing to fight the Capitalists with but the guns and forts of the Transvaal... If the English government once gains control ... South Africa may and almost must fall into the hands of the Capitalists ..." That, for [Will] Schreiner, was decisive'. ${ }^{46}$ This provides another instance where Walker sees Olive Schreiner's influence as direct and decisive, but the specifics of why he does so are not detailed.

After the South African War (1899-1902), the question of the political relationship between the white settler states was immediately on the agenda. Regarding this, Walker states that ' ... just before the ultimatum [starting the war], Olive had written him a letter on the subject [of federation] which had set him thinking, as so many of her shrewd letters did'. ${ }^{47}$ He links Will's shift from supporting Union, to supporting a looser federation with internal checks and balances, with this letter, commenting that by 1908 , 'It must be federation or nothing, for not only did [Will] share with his sister Olive the belief that small states were .... more favourable to liberty ... but ... that the federal principle was peculiarly applicable to South Africa ... In a legislative union ... the Cape's liberal policy would be in constant danger' ${ }^{48}$ This was, indeed, Olive Schreiner's position, and in a letter to Will she marshals her arguments and wonders 'on what a thoughtful mind like yours bases its desire for Union' ${ }^{49}$ One of her suggestions was 'Stand by the side which is for the moment weakest ... Our day will come $\&$ England will have to honour a cheque endorsed by Justice ... Always follow your little sister's advice \& you'll get to heaven at last' ${ }^{50}$ Will Schreiner did precisely this and resigned office on 13 June 1900, stating the need for a more conciliatory approach to the punishment of Cape Colony men who fought as rebels during the war. Again, Will's change of mind and its timing are highly suggestive, but no more 
direct evidence than this exists regarding Olive Schreiner's influence on him in this matter, however likely and supported by circumstantial evidence it may be.

Will Schreiner's political views and practices continued to change. His 1908-9 defence of the Zulu king Dinuzulu, and then post-1910 his role as an elected senator representing black people in parliament, signify a more general liberalising of his political views, which eventuated in an invitation from the 1909 black delegation that went to Britain to protest against the draft of the South Africa Act to lead it. Our fourth example concerns the fact that by the end of 1913, Will had also become a public supporter of women's and black suffrage, in one speech emphasising 'the subject we are discussing [women's franchise] and the object we have to serve are indissolubly connected with the abolition of all prejudices, and I class the discrimination on grounds of sex with the fearful discrimination against humanity on the ground of race or colour' ${ }^{51}$ Walker comments that Olive Schreiner and Will's eldest daughter Lyndall were significant figures in the women's suffrage campaign, implying this is why his views changed. However, of more relevance is that Olive Schreiner was a full adult suffragist, and she insisted that no franchise measure should be supported which did not bestow full political rights to black people as well as white women. It seems to have been this adult suffrage position that Will Schreiner was influenced by - his franchise speech was made in the context of the introduction of a Natives Land Act by an increasingly retrogressive Union government and his speech expressed his recoil from it enshrining segregationist and discriminatory principles. ${ }^{52}$ This is, again, a major change from his earlier approach to franchise matters, and once more it is a move in the direction of his sister's views and political advice to him. But once more there is no incontrovertible evidence of a causal link.

Over the course of his political life, Will Schreiner became demonstrably more liberal, in particular regarding race matters. His sister's letters to him exhorted, cajoled, persuaded and advised him that he should move politically in the direction that he, in fact, did move in. As Olive commented to her close friend Betty Molteno, 'My dear brother seems becoming much more liberal on the native question. But I never argue with him. Seeds grow quickest under ground'. ${ }^{53}$ Walker frequently states that her $\overline{\text { shrew }}$ dness and advice were 'decisive' and led Will to change. However, his political biography is very much of its day in its absence of chapter and verse references to substantiate factual claims and its failure to document the privately held sources and first person knowledge made available to him. Consequently, while Walker's insistence that Schreiner was a 'key influence' on her brother has to be taken seriously, he provides no direct and incontrovertible evidence for this. ${ }^{54}$

We have discussed Walker's case for Olive Schreiner's political influence on Will Schreiner in detail because of Walker's certainty about this. However, looking closely at the four key examples we have taken from Walker, it is not so open and shut as he assumes because, as we have shown, his claims are not backed by precise detail. With the exception of Butler's letter, the epistolary and other evidence which might have demonstrated Olive Schreiner's influence over Will in a more direct and indisputable way is no longer available, or perhaps never existed in writing. Consequently, we shall now move on to consider her influence in a different way. This is by considering the links between her letters and her published work as an author. Schreiner's published writings were internationally renowned, and there is ample evidence in the form of translations, sales figures, new editions, reviews and a host of written comments in 
letters, autobiographies and memoirs by readers, attesting to their influence. Schreiner's letters to John Merriman provide an interesting example to discuss her influence, for Merriman was both repeatedly generous in his praise of Schreiner's published work, and a determined opponent of one cause she held dear, women's enfranchisement, and also an uncertain supporter of another, the cause for black equal rights.

\section{'If ... a law were passed, that you, John X. Merriman, were not a fit \& proper human being' - influence across Schreiner's letters and her published writings}

Merriman was a cabinet minister in various Cape administrations from 1875 onward and became its last Prime Minister in the period immediately before the Union of South Africa, that is, from 1908 to $1910 .{ }^{55}$ Merriman parted company from Rhodes after the Jameson Raid and increasingly cooperated with the Afrikaner Bond, to the extent that he became a key protagonist in ensuring Union around a racial - indeed, racist - principle which governed not only the franchise but also denied other rights to black people. A politician through and through in a way that Will Schreiner never was, Merriman, like the other Cape liberals Sauer, Innes and Malan, did not operate on fixed principle but by making deals to ensure himself high political office. ${ }^{56}$ For Olive Schreiner, how he and these men conducted themselves seriously weakened the liberal grouping in the Cape parliament. Her letters to Merriman on this and related matters are among her most fascinating, displaying her intellectual prowess and political acumen. Across the period 1896 to 1913, these letters argue with, flatter and persuade Merriman that his voting record and other political behaviours ought to match his proclaimed liberal principles. Examples particularly relevant to the present discussion include Schreiner's lengthy endeavour to persuade Merriman to put his principles regarding the 'native question' and black political rights into practice, and also to convince him that women should be treated equally with men and that he should support (or even just not oppose) women's enfranchisement measures.

Presciently, by the early 1890s Schreiner was convinced that race would become the defining issue for South Africa. In one of her many arguments to Merriman, she insists that 'a course of stern unremitting justice is demanded from us towards the native, $\&$ that only in as far as we are able to raise him ... can the future of South Africa be anything but an earthly Hell', and so Merriman and the other liberals should stop supporting retrograde legislation for the sake of short-term political gain. ${ }^{57}$ Schreiner perceived the push for Union in these terms, that is, it was at basis concerned with cheap labour and black subjugation. She attended the debates about Union in the Cape parliament and wrote to her brother about the occasion when Union was passed:

That scene in the house yesterday, was without any exception the most contemptible from the broad human stand-point I have ever seen in my life ... they squirmed \& lied, \& each one giving the other away, \& all gave away principle . . Men selling their souls $\&$ the future $-\&$ fate watching them. ${ }^{58}$

'They' included Malan, and the 'fate watching' in this letter was embodied by Dr Abdullah Abdurahman, leader of the African People's Organisation representing the coloured populations of the Cape and more widely, who had sat next to Schreiner and had also observed the reneging on principle occurring. And just as Schreiner predicted in her letters and in her essay Closer Union, once Union was achieved then a succession 
of racially and politically retrogressive legislation was pushed through with full support from the erstwhile Cape liberals, including Malan, who she had hoped would resist this.

At the end of their epistolary friendship, Schreiner wrote to Merriman about the 1913 Natives Land Act, the most notorious of such legislative onslaughts on black rights because it was the founding basis of apartheid legislation after 1948, that 'I thought your speech on the Native Bill very fine, but oh if you could have seen your way to vote against the Bill!! ${ }^{59}$ Her 'but oh' and exclamation mark speak volumes this is the last proper letter Schreiner wrote to him, and she ceased writing because of the way he had voted. As with Malan, Schreiner's argumentative and exhortatory letters to Merriman ended once she concluded he had crossed a line beyond which there could be no persuading him to behave in a more principled way. In Merriman's case, this concerned the Land Act; in Malan's, it was Union and his reneging on promised support for black and women's enfranchisement.

However, whatever the complications of evaluating Merriman's response to Schreiner's political analyses and prognostications in her letters, as soon as her published writing appeared in the public domain he wrote appreciatively to her regarding its ethical stance and message. That is, it is difficult to evaluate the influence of Schreiner's letters on Merriman, but evident that he greatly respected her published work. Merriman was, in fact, among the few white South Africans to praise her allegorical novella Trooper Peter Halket of Mashonaland. ${ }^{60}$ This book was highly controversial in condemning massacres carried out by Rhodes's Chartered Company troops in what is now Zimbabwe and naming Rhodes as personally responsible. ${ }^{61}$ She wrote to Merriman, 'I am indeed glad of your opinion of Peter Halket', ${ }^{62}$ while to Will Schreiner she explained in more detail:

\footnotetext{
Dear old John X Merriman... sent me quite a touching little note when he passed here to go up. However we may differ on the woman question... I can never forget that he was the one, only, human creature in South Africa... who wrote me one word of sympathy when at so much terrible cost to myself I brought out Peter Halket. His letter was not only sympathetic ... it came straight from the heart, \& his letters \& view of all things generally come entirely from the head. ${ }^{63}$
}

This highlights the importance of the links which existed between Schreiner's different genres of writing; and whilst recognising the significance of her letters, it is important not to neglect or downplay the impact of her published work. It also raises the complexity of her response to Merriman - and his to her.

Schreiner's 'we differ' comment in the letter above alludes to what was generally seen as Merriman's highly negative stance regarding women's participation in public and professional life. She was consequently reluctant to debate the woman question with him because it was a subject which, as she put it, 'lies so near to my heart, touches me so deeply that I can hardly dis-cuss it as an indifferent matter' ${ }^{64}$ But she did try to explain her position, including encouraging him to put himself in the situation of women:

If you, John X Merriman were for five years owing to illness, business or absence from home, to abstain from casting your vote it would probably not appreciably affect the country, \& not by a little affect your personal health, wealth, happiness or freedom ... But if a law were passed, that you, John X. Merriman, were not a fit \& proper humanbeing to exercise the vote \& prohibiting you from doing so, then in a moment the matter would become one of primary importance, worth fighting 
over \& perhaps even under certain conditions laying down your life for. So small a thing in itself it would yet indicate your place in the society of which you form a part, your relation to your fellow men in a hundred ways, $\&$ so be of vital import. ${ }^{65}$

In spite of Merriman's known views, Schreiner's letters to various people in 1911 comment with amazement about a letter he sent her about Woman and Labour, published at the start of the year. ${ }^{66}$ To her sister Ettie, for instance, she wrote with an atypically large number of exclamation marks:

You know what a bitter opponent of any emancipation for women old Merriman has always been. I don't know if you remember his speech when the bill was introduced into the house! My book hadn't been six days in Cape Town when I got a long letter from him, saying how much he had enjoyed reading the book... the old fellow is always looking up favourable reviews of the book, $\&$ wrote yesterday to tell he "was delighted to find a most sympathetic review in the 'Economist'... - which he was going to send me! It's quite touching if you knew how bitter he was - he couldn't even talk of ^the^ woman's movement without getting in a rage $!^{67}$

Why did Merriman write this letter and send her the reviews? It could be argued that Schreiner influenced Merriman in broad ways in her published writing, while her letters expressed political views antithetical to him that he ignored. But it is not as straightforward as this because Olive Schreiner's writing and her letters are not so easily prised apart: her letters are not separate from her social theorising and they articulate views which also appear in her published work. Schreiner's letters to Merriman discuss, under the banner of 'I can hardly discuss at all', many of the same ideas which appeared in Woman and Labour and which were initially expressed in her letters, including in those to Merriman. Would a man militantly opposed to women's rights have responded so positively to Woman and Labour if Schreiner's letters had not engaged with him on this over a lengthy period? The common-sense interpretation of the change here is that the views expressed in her letters were persuasive and slowly influenced him, so that when he came across them in her published work he was already predisposed to react more favourably that she had anticipated.

However, in order to find any decisive, less circumstantial evidence of Schreiner's influence on Merriman, an investigation of the entirety of his epistolary and related textual activities, and those of his major correspondents, would be needed to search for documentary proofs. This would be both an enormous task and also might yield no result because he might not have written about this to any of his correspondents. Therefore, we now discuss an example where Olive Schreiner's political influence is fully demonstrated, outline the particular circumstances which produced the document in question and consider the certain proofs it provides of Schreiner's influence.

\section{'Always give your enemies what they don't want!' - marks upon the text}

Schreiner's 1899 political essay An English South African's View of the Situation warned that a war between Britain and the Boer Republics would be hard fought and devastating on both sides, rather than the British walkover many imagined. ${ }^{68}$ The essay originated in the political analysis and strategising in her 'private' letters and also in the open letters she published in a range of newspapers. This particular essay started as an open letter in a newspaper and was expanded to a pamphlet and then a short book, and it achieved high sales and was rapidly translated into many world languages. 
Schreiner and other political figures, particularly in the Transvaal and Free State, saw it as an important part of the anti-war and pro-Republican campaign, viewing her letter/pamphlet/book as politics rather than just about this. Schreiner wrote to Jan Hofmeyr about it, that:

I hope you received the copy of my paper on the Situation which I sent to you. I am going to republish it in pamphlet form ... Will the Bond care to take any copies, \& if so how many, at $3 \mathrm{~d}$ each. Iha I cannot afford to republish it unless I know a certain number will be taken . . . I am going to have it translated into all the European languages ... Always give your enemies what they don't want!... If you think the Bond would order any of pamphlets, please wire to me Box 406 Johannesburg. ${ }^{69}$

Hofmeyr was not only leader of the Bond but also the most influential politician over many years in the Cape, with very strong links with Boer/Afrikaner politicians and organisations elsewhere too. Schreiner's letter makes a number of assumptions, in particular that Hofmeyr would share her view of the importance of her paper, and also that their unnamed 'enemies' would as well. This might seem vainglorious - except for the certainty provided by Hofmeyr's notes to his secretary on the back of the letter, which concern its importance and how it was to be responded to:

\section{R 7-6-99}

Moloy ordered 100. Send 400 C. P. Schultz \& acc to me.

I appreciate enthusiastic labours our common cause. Your burning words find entrance where nobody else can.

I think Kruger displayed an unexpectedly liberal spirit at BFT. am sure he could have done a great deal more if he had been encouraged by the other side. This morning wired to a Bloemfontein friend: -

(Insert wire to Fischer) 'I deplore' \&c)

He replied this afternoon

(Fischer's wire 7th June) 'I fear my friend does not see that by not making concessions which $\mathrm{H}$ Exc did not ask for then Kruger would be playing enemy's game. ${ }^{70}$

Hofmeyr's notes provide a number of instances of actions which were to be taken in direct response to Schreiner's letter. Firstly, two separate orders for copies of her essay were placed, with Hofmeyr and the Bond paying for the largest. Secondly, Hofmeyr replied to her in extremely flattering terms about her 'burning words finding entrance' and in doing so he provided her with highly confidential information about Kruger, President of the Transvaal, during a Bloemfontein conference negotiating with Milner. Thirdly, Hofmeyr instructed the secretary that she should be sent his telegram to Fisher, one of the envoys whom Will Schreiner had sent to the Republics. And fourthly, he also instructed the secretary that Fischer's reply to himself should be sent to her as well. There is nothing circumstantial about discerning the impact of Schreiner's influence here, the proofs are certain.

Finding clear and incontrovertible demonstration of Schreiner's influence as in Hofmeyr's notes and the more complex example of the Butler letter sent to her by her brother is rare. So does this mean that only circumstantial claims can be made about Schreiner's political influence, apart from in such specific instances? So far we have assumed that demonstrating influence requires a directly evidenced change in someone's expressed views or behaviours, as with the Hofmeyr example, of a cause and effect kind. However, there is another way to think about the influence and impact of letter writing, which is to conceive this in epistolary and textually oriented terms 
which are 'to the letter'. That is, to focus on the specifically epistolary forms that influence and impact might take. We now turn to a consideration of this and how this approach might help forward our epistemological inquiry about Schreiner's influence as a feminist protagonist in the political landscape of the Cape Colony.

\section{Doing things with letters: the performative character of Schreiner's epistolary activities and influence}

The idea of an epistolarium has been central to our understanding and analysis of the (extant and the missing and presumed destroyed) letters written by Olive Schreiner and other people who engaged in high-volume letter writing. ${ }^{71}$ In the case of Schreiner's letters, conceptualising the shape and concerns of her epistolarium suggests there are characteristic features of it, both overall and with respect to particular correspondents. These characteristics can provide helpful ways of exploring the influence and impact of her letters in ways that do not rely on externalist measures of this. Of particular relevance here is the performative character of many of Schreiner's letters. Here we use 'performative' in the J. L. Austin, technical sense of 'how to do things with words'. 72 That is, the term performative does not mean 'a performance' for Austin but has the more rigorous meaning of words or phrases that actually do the thing they are about: the immediately legally binding character of ' $\mathrm{I}$ do' in a marriage ceremony is one example Austin provides. 'I promise to pay the bearer on demand', written on British banknotes and signed by the Bank of England's chief cashier since 1694, is another and reminds us that banknotes originated as handwritten promissory or signed IOU letters.

The first kind of performative letter writing which Schreiner engaged in can be shown by an example where she initiated a political friendship in the context of the Cape Women's Enfranchisement League (WEL), writing to a Mrs Goosen:

\footnotetext{
My friend Mrs Haldane Murray has just written to tell me how hard you are working for us at Cathcart. This is just to hold out a hand of friendship to you. I know how difficult it often is to start a new thing in an up-country, but once started, \& when our women really understand the the great good, not only to themselves, but to men \& all the nation, the freedom of women will bring, I believe our South African women will be even more earnest \& successful than others. ${ }^{73}$
}

This letter in itself constitutes 'the hand of friendship' that Schreiner writes of holding out to Mrs Goosen. Metaphorically, it is the hand of the WEL; and later in this letter it is also extended to Mrs Goosen's husband as well, by invoking Schreiner's husband and enclosing a political pamphlet by him that was to be given to Mr Goosen. The effect is that her letter does not so much welcome Mrs Goosen to the WEL fold, as confirm that she is already part of it. Schreiner's inclusive phrasing - 'us', 'you', 'our women' and so on - reinforces this effect of producing the friendship within the letter. Performative ways of opening up and confirming friendly relations also have a more general place in how Schreiner's letters achieve influence and impact. Many examples occur from the 1880s on in the context of her feminist friendships, including in letters to Alys Pearsall Smith, Beatrice Potter (later Webb), Mary Sauer, Fred and Emmeline Pethick-Lawrence and others; and later from 1914 to 1918 this occurs in her letters to people in pacifist networks too, including such feminist notables as Jane Addams, Aletta Jacobs and Catherine Marshall. 
The second kind of performative letter writing engaged in by Schreiner acts as a closure and is in itself the closing that her letter states will happen:

I can't write to you about public matters. I personally have never wished Gladstone to be recalled, nor did I think your ministry ought to resign. Would he gain anything better by it? But I am opposed to Botha's silly Imperialism when he talks English, \& narrow back-velt-ism when he talks Dutch!! Give my love to your wife, $\&$ the dear children. I hope the young generation will live to see a nobler broader, less racial spirit than we see in South Africa to-day. ${ }^{74}$

This letter marks the end of the powerful correspondence between Schreiner and Malan. Although her 'I cannot write to you again' statement is followed by three comments on political matters (Herbert Gladstone's recall, Prime Minister Botha's conduct, and racialism), these were in fact the last things Schreiner wrote to Malan. Literally, she would not write to him again, and in this example she finalised the correspondence by having three 'last (political) words', the third of which acts as a final comment on Malan himself, one of the older generation with a more racial less noble approach. Schreiner sent a very similar last letter to Merriman, written in the context of retrograde political events which ended Schreiner's hope that his political behaviour might become more actively liberal. In addition, performative last letters which operate a closure have a more general place within Schreiner's political armoury. Important examples, for instance, occur in the context of women's suffrage in South Africa, when erstwhile colleagues adopted a policy of 'on the same terms as men' and therefore supported a racial basis to women's suffrage. ${ }^{75}$

The third kind of performative letter writing by Olive Schreiner assumes and in itself demonstrates a favourable view of her political judgement and position which was shared by her and her correspondent. This can be seen particularly clearly in letters acting as a recommendation of a particular person and/or the political cause they were representing. For instance, she provided a number of people with epistolary introductions to the Transvaal politician Jan Smuts and his wife Isie Smuts, to her Dutch feminist friend Aletta Jacobs, and to the British Labour Party leader Keir Hardie, as well as to Will Schreiner. Schreiner sent one such letter directly (rather than to the person concerned) to her brother Will, then Prime Minister of the Cape in wartime, concerning a Reuters journalist who had been sent to head its South African office:

Yesterday we had a man to lunch with us Collins, Reuter's General Manager in Australia. He is a man of considerable intelligence \& much influence in journalistic world. He is on his way to England will see Lord Salisbury \&c. We tried to let him into the ?inwardnessof affairs here a little... He has a letter of introduction to you from the ${ }^{\wedge} \mathrm{an}^{\wedge}$ Australian Premier ... Introduce him to Hoffmeyr \&c \& sh He's rather a good sort, clear \& sharp. Could be very useful at home. ${ }^{76}$

While Collins was provided with a letter of introduction from the Australian Prime Minister to present to Will, Schreiner takes it for granted that Will would find her own letter a more trustworthy guide. She also wrote many letters of introduction for women, including to secure access for her much loved nieces to British feminist circles and also to attest to the suitability of women she knew for humanitarian war work over the period 1914 to 1918 . The common feature of this kind of letter writing is that tacitly it 'works' because of a shared evaluation on the part of the person making the request, the addressee of the letter and by Schreiner herself, concerning Schreiner's value or reliability in recommending someone. 
The character or public persona of 'Olive Schreiner' was clearly pivotal in ensuring the performative character of these letters of introduction; that is, this persona was the guarantor of the intended outcome, which was ensuring someone had an entrée into a new political network. However, that Schreiner had such a character or persona was the result of continued activity, rather than it being an innate quality or attribute. Her published writings were obviously of importance here, but so too was her letter writing, in particular her brokerage letters. This is the fourth kind of Schreiner performative letter writing we want to discuss, and it relies on her public persona being accepted as a guarantor in trading political favours. That is, such letters in themselves broker political effects by doing political favours in both directions. An example here involves Schreiner brokering for Adele Chapin. ${ }^{77}$ Chapin was in South Africa in 1899 to 1902, acting on behalf of British Colonial Secretary Joseph Chamberlain and Governor Alfred Milner, and she wanted to secure her entrée into Transvaal political circles and political information. Schreiner wrote to Jan Smuts, then State Attorney and a key political figure in the pre-war Transvaal, about this. ${ }^{78}$ She commented:

I am coming over to Pretoria on Friday next with an American friend Mrs Chapin ... I know you are too busy to spare much time, \& Mrs Chapin is very anxious to meet you... She is a great friend of unreatable the Governors \& in constant correspondence with him; she also knows the Chamberlains with whom she will probably stay on her return to England; ^ as she did before she came out here, ${ }^{\wedge}$. . . anything said will go straight to Chamberlain - unreadable Milner ... ${ }^{79}$

Schreiner also wrote to her brother Will on the same matter, clearly realising that Chapin was a kind of unofficial spy for Britain:

\begin{abstract}
There is an American friend of mine staying at Mount Nelson hotel for some days on her way from Johannesburg to England. ^Mrs Chapin^She is a great friend of Mrs Chamberlain's \& Milners. She was very anxious to meet you. I told her I could not possibly promise that you would call, but that I would ask you to if you have time. She might give you some interesting news about the League in Johannesburg as she knows much. She is sympathetic to our side, but of course all you say may go straight to Chamberlain \& Milner. ${ }^{80}$
\end{abstract}

These letters were written in the run-up to the South African War (1899-1902), with Schreiner's knowledge - conveyed in both of the above letters - that what Adele Chapin heard would most likely go to her political masters. In her letter writing, Schreiner's being in the know and well connected on this matter was demonstrated to both Adele Chapin and Jan Smuts, and thereby increased Schreiner's political status in the eyes of both. It enabled the Transvaal to convey, through a source they would trust because in a sense guaranteed by Schreiner, the political information they wanted Chamberlain and Milner to receive. It would also have had the effect of increasing Chapin's marketability as a successful peddler of to-be-trusted information with both Britain and the Transvaal, again guaranteed by Schreiner's intervention. And Schreiner's related brokerage letter to Will Schreiner indicates how thoroughly her political strategising and brokering was engaged in, working across a range of relationships that transcended any separation between personal and political spheres.

Thinking of Schreiner's letters in their own terms by drawing on Austin's ideas about the performative in the technical sense of a letter doing the very thing it is about, provides a fruitful means of discerning the range of ways in which her letters had direct influence and impact. Doing so makes clear how much influence and political importance Schreiner had and the varied ways in which she secured influence within 
and across different networks and contexts. While the discussion here has focused on an earlier period, later examples also abound and could have been provided regarding, for instance, her political lobbying around war and pacifism while in Britain from 1914 to 1920 (including for instance demanding and being granted an interview with Lloyd George on the outbreak of the Great War in 1914), and her involvement in helping raise money for the defence of the South African trades unionist Samuel Masabala and other black political causes in 1920. Relatedly, the performative is an important aspect of Schreiner's letters more generally, as our comment that all four of Schreiner's key performative forms of letter writing have more general expression, in addition to the particular examples provided here, will have indicated.

\section{A feminist protagonist in a masculine political landscape: on influence and separate spheres}

We have reviewed Olive Schreiner's influence on the political views and behaviour of a number of well-known figures within the political landscape of South Africa, using the examples discussed to raise a general epistemological issue facing all historical scholarship, gender history included: how can impact and influence in the historical past be convincingly demonstrated. In all the examples discussed, there is reasonable certainty that Schreiner did have influence, for the weight of circumstantial evidence strongly supports this. But showing such influence in the stronger terms of certainty backed by direct evidence has proved difficult, apart from in the two exceptional instances of Hofmeyr's notes and Butler's letter. However, rethinking notions of influence and cause and effect by focusing on the frequently performative character Schreiner's letters conveys that in a number of ways her letter writing had direct effects for the addressees of her letters. Succinctly, these letters in and of themselves changed things. The performative dimensions of letter writing, we suggest, need to be encompassed in thinking about influence and its proofs, rather than these being conceived as always lying outside the text. Texts and words can have powerful effects, not just 'things' in a narrower material sense.

We conclude that Olive Schreiner 'just expressing my views' in her letters did in fact have undoubted effects and demonstrable influence in the masculine political landscape, and we hope to have argued this 'to the letter' in ways that readers will find convincing. But where does this take us in responding to the epistemological and ontological questions introduced earlier? An immediate response (we elaborate later in the conclusion) is that matters of ontology or 'being' are at the heart of epistemological issues about knowing, and this has consequences for how to understand the historical landscape and the gendered relationships and spheres which characterise it. That is, earlier we noted Abrams's comment that working from the supposed peripheries rather than the 'metropolitan heart' necessitates (or should) a change of perspective, a shift to a feminist historiography conceived around narratives of women whose sense of the past included their own contexts, as she puts it. ${ }^{81}$ This change of perspective is what we have endeavoured to provide here, together with a glimpse of an alternate history of a momentous period in the South African past. We have done this by exploring Schreiner's epistolary perspectives on and interventions in South Africa's masculine political landscape, as one of the keenest minded feminist 
social theorists of her generation and later. And we hope this approach has also restored her to view as a shrewd and effective political strategist who had considerable influence. $^{82}$

Looked at in relation to the historical time period of their writing and the network of correspondents they were written to, Olive Schreiner's letters can be seen as not only hugely important because of their content, but also as ontologically and epistemologically complex in the sense that their meaning for their addressees and also their influence and impact are not immediately transparent. Working in a referential frame concerning letters as historical documents perceives them as problematic because they are perspectival, tailored 'to the person' who is the addressee and lack direct referential properties - they are part of context, but in a way often deemed by researchers to be somehow faulty. However, it is their perspectival, dialogical, emergent, temporal and serial characteristics that underpin the fascination of letter writing for feminist historiography as we practice it. As we have shown, these characteristics are not deficiencies but strengths because they provide an analytical purchase on understanding context and its dynamics. That is, letters do not need to be 'the facts' and nothing but this in order to have impact and influence. Context, then, needs to be thought about in ways which include letter writing, reading and replying and the importance of this in cultural and personal life.

A large collection of letters like Olive Schreiner's has interesting characteristic features, presences and absences and changes in people's letter writing over time can be explored by drawing together things which more conventional scholarship usually keeps separate. In her case, these include her published writing, political practices and social networks as well as her 'private' letters. And as we have shown, by working with the grain of epistolarity rather than against it, and relatedly by exploring the performative in the Austin sense, many examples of the direct influence of Schreiner's letters come into view. There are, we have proposed, appropriate and sufficient ways of showing the influence of Schreiner's letters outside of the narrowly referential. Recognising the performativity of many of her letters throws light on the letter writing itself, and it also connects these letters with 'real-life' as experienced by new members of suffrage campaigns, amateur spies, worried politicians and newspaper men moving jobs, among others. Succinctly, Schreiner's letters, not just her published writings, were influential and had demonstrable impacts in the highly masculine political landscape of South Africa of the time, and they did so in the range of performative ways we have explored. In addition, if her letters had influence like this, then other people's letter writing will have done so too, which opens up for consideration the possible influence of 'others' more generally, and in particular white women and black people and how they too might have made their mark - but alas not mark enough - upon the evolving political context of South Africa. ${ }^{83}$

Using Schreiner's letters as a focus for discussion has, we hope, fleshed out our earlier comments about the complexities of separate spheres in the South African context and the intertwining of gender and race in this. A binary way of thinking about separate spheres is both helpful and unhelpful when thinking from this particular colonial periphery, for the gendered and raced separations strongly marking the white enclaves of South Africa were sometimes super-exaggerated but also frequently traversed and in Schreiner's case at times almost dissolved. ${ }^{84}$ Contra the tenor of arguments from Davidoff and Weintraub, we conclude that what is needed in analytically 
responding to this complexity is not to reify fractures of public and private, but instead to adopt a more radical approach and dismantle such binary ways of thinking. ${ }^{85}$

In South Africa over Schreiner's lifetime, separate spheres thinking and its practices were enshrined but also massively undercut by unacknowledged presences, including economically powerful Boer matriarchs, redoubtable frontierswomen, strategising feminists, the omnipresence of black people in 'white' spaces which were entirely dependent on their skills and labour and a rapidly emergent and active black intelligentsia. Coexisting with such complexities were the self-perpetuating white oligarchies which formed the governments of the four settler states and conceived the world using gendered and raced binaries. And so how is the political strategising of Schreiner as a feminist protagonist to be understood against the distinctive and extremely complicated backcloth of this political landscape? Her performative letters took shape and had the influence they did in this framework and their impact certainly cannot be classified or measured by reference to binary notions of public and private, personal and political. Consequently we note with interest some root and branch reconceptualisations of separate spheres thinking, and in particular Peggy Watson's interesting idea of a 'curved space' created by the political actors that it simultaneously creates. For Watson, 'rather than acting "within" political space or being prevented from doing so by virtue of space's lack, [political actors] instead constitute as they are constituted by a specific political "curved space". ${ }^{86}$ This accords with our research on Schreiner's letters and their complex interfaces with social and political life; and in association with recognising the strong heterotopic aspects of letter writing in inscribing a kind of parallel 'other place', such rethinking provides useful tools for feminist historiography working at the assumed margins and peripheries of masculine political landscapes. ${ }^{87}$

Kathleen Canning suggests that "[t]he gender history of the future is one that can confidently admit the possibility of disparate temporalities. Rather than attempting to fit gender back into established chronologies and categories, its more productive outcome may be to allow dissonance within grand narratives'. ${ }^{88}$ We have explored such disparate temporalities and narrative dissonances in connection with Olive Schreiner's letters in order to show how this particular feminist protagonist was able to achieve influence in the masculine political landscape of white South African political life. We look forward to a gender history which actively promotes, not just allows, such dissonance within its narratives. Regarding the microhistory of the particular place and experience we have discussed, Schreiner's letters show that in some historical circumstances gender dynamics and separate spheres may be neither so binary nor so impermeable as once supposed, and also, they hint at the existence of alternative motors of change and the fascinating might-have-been of a very different South African future. That 'could have been' future was still a possibility when Olive Schreiner began writing her letters in the 1870s, but not when she came to terminate some of the correspondences considered here.

\section{Notes}

The Olive Schreiner Letters Project is funded by the Economic and Social Research Council (ESRC) (RES062-23-1286); we gratefully acknowledge the ESRC's support. We are grateful also to the organisers of the Minneapolis Workshop on 'Gender History Across Epistemologies', University of Minnesota, 15-16 April 2011, and to Patricia Lorcin, who moderated the session on 'Reading Letters Across Epistemologies' and provided helpful comments. Thanks to Donna Gabaccia and Mary Jo Maynes and the anonymous reviewers for Gender \& 
History for detailed comments on our original article. In addition, Liz Stanley thanks the Sociology Department of the University of Pretoria, where much of the research and thinking for this article occurred as part of a Visiting Professorship.[NB. The access dates for all website references is 6 February 2012]

1. Olive Schreiner to Betty Molteno, 17 June 1900, <http://www.oliveschreiner.org/vre?view=collections\& colid $=92 \&$ letterid $=34>$. All transcriptions are precisely 'to the letter' and include the omissions, insertions, deletions and mistakes of the originals; ${ }^{\wedge}$ this $^{\wedge}$ indicates an insertion, this is a deletion, and this is an underline, in the original letters.

2. See Ruth First and Ann Scott, Olive Schreiner: A Biography (London: Andre Deutch, 1980); Joyce Berkman, The Healing Imagination of Olive Schreiner: Beyond South African Colonialism (Oxford: Plantin Publishers, 1989); Anne McClintock, Imperial Leather: Race, Gender and Sexuality in the Colonial Context (London: Routledge, 1995); Carolyn Burdett, Olive Schreiner and the Progress of Feminism (Basingstoke: Palgrave, 2001); Liz Stanley, Imperialism, Labour and the New Woman: Olive Schreiner's Social Theory (Durham: Sociology Press, 2002); Liz Stanley, "'Shadows Lying Across Her Pages": Epistolary Aspects of Reading “The Eventful I" in Olive Schreiner's Letters 1889-1913', Journal of European Studies 32 (2002), pp. 251-66.

3. Olive Schreiner, The Story of An African Farm (London: Chapman \& Hall, 1883).

4. In late 1913, as Schreiner prepared to leave South Africa, she destroyed letters sent to her and asked her correspondents to destroy hers to them. Valuing the work people did and seeing 'the life' as incidental to this, she was opposed in principle to 'biographising' and wanted to prevent it happening to her. She also foresaw her letters and those to her being bought and sold in a marketplace, and wanted both to protect her correspondents and to stymie this. For the Olive Schreiner Letters Online, see $<\mathrm{http}$ ://www.oliveschreiner.org $>$ and for project research publications, go to <www.oliveschreiner.ed.ac.uk/TeamPublications.html $>$.

5. For an overview of Cape and wider politics of the time, see T. H. R. Davenport and Christopher Saunders, South Africa: A Modern History (Basingstoke: Macmillan, 2000), pp.194-299. On key Cape liberals and 'Cape liberalism', see Peter Kallaway, 'F. S. Malan, the Cape Liberal Tradition, and South African Politics 1908-1924', Journal of African History 15 (1974), pp. 113-29; Phyllis Lewsen, John X. Merriman: Paradoxical South African Statesman (New Haven and London: Yale University Press, 1982); Phyllis Lewsen, 'The Cape Liberal Tradition - Myth or Reality?', Race 13 (1971), pp. 65-80; Rodney Davenport, 'The Cape Liberal Tradition to 1910' in Jeffrey Butler, Richard Elphick and David Welsh (eds), Democratic Liberalism in South Africa (Middleton, Connecticut: Wesleyan University Press, 1987), pp. 21-34. Some historians reject the idea of liberalism in this context. Although by European standards they by no means fitted the liberal concept, these politicians were 'relatively liberal' and were known as liberals in the South African context explored here. Thus our usage. The Afrikaner Bond was established in the Cape in 1880 to oppose British imperial influence and promote South Africa-wide Boer interests. From the 1880s, it was under the control of Hofmeyr, who had a more conciliatory approach. Until the mid-1890s the Bond exerted political influence chiefly by entering into alliances with politicians who would promote its concerns. It later gained direct political power in the Cape parliament. See Mordechai Tamarkin, Cecil Rhodes and the Cape Afrikaners: The Imperial Colossus and the Colonial Parish Pump (London: Cass, 1996).

6. See Barbara Welter, 'The Cult of True Womanhood: 1820-1860', American Quarterly 18 (1996), pp. 151-74; Leonore Davidoff and Catherine Hall, Family Fortunes: Men and Women of the English Middle Class, 1780-1850 (1987; repr. London: Routledge, 2002); Mary Poovey, Uneven Developments: The Ideological Work of Gender in Mid-Victorian England (Chicago: University of Chicago Press, 1988); Jane Rendall, 'Women and the Public Sphere', Gender \& History 11 (1999), pp. 475-88; Joan Landes, 'Further Thoughts on The Public/Private Distinction', Journal of Women's History 15 (2003), pp. 28-39; Mary Ryan, 'The Public and the Private Good: Across the Great Divide in Women's History', Journal of Women's History 15 (2003), pp. 10-27.

7. See Cameron Macdonald and Karen Hansen, 'Sociability and Gendered Spheres', Social Science History 25 (2001), pp. 535-61; Cathy Davidson and Jessamyn Hatcher (eds), No More Separate Spheres (Durham: Duke University Press, 2002); Mary Ryan, 'The Public and the Private Good', pp. 10-27; Joan Scott and Debra Keates (eds), Going Public: Feminism and the Shifting Boundaries of the Private Sphere (Urbana: University of Illinois Press, 2004); Alison Piepmeier, 'Stepping Out: Rethinking The Public and Private Spheres', Journal of Women's History 18 (2006), pp. 128-37; Lynn Abrams, 'The Unseamed Picture: Conflicting Narratives of Women in the Modern European Past', Gender \& History 20 (2008), pp. 628-43; Jeanne Boydston, 'Gender as A Question Of Historical Analysis', Gender \& History 20 (2008), pp. 558-83.

8. Abrams, 'The Unseamed Picture', pp. 640-41.

9. For overviews of the changing configurations and dynamics of race in South Africa, see William Beinart and Saul Dubow (eds), Segregation and Apartheid in Twentieth-Century South Africa (London: Routledge, 1995) and Paul Maylam, South Africa's Racial Past: The History and Historiography of Racism, Segregation 
and Apartheid (London: Ashgate, 2001). See also Simon Dagut, "Gender, Colonial "Women's History" and the Construction of Social Distance: Middle-Class British Women in Later Nineteenth-Century South Africa', Journal Southern African Studies 26 (2000), pp. 555-72.

10. Regarding notions of separate spheres, for the early period in South Africa see Kirsten McKenzie, 'Women's Talk and the Colonial State: The Wylde Scandal, 1831-1833', Gender \& History 11 (1999), pp. 30-53; and in other colonial contexts see Penny Russell, A Wish of Distinction: Colonial Gentility and Femininity (Melbourne: Melbourne University Press, 1994).

11. This was a product of the character of white migration to South Africa and the kind of colonial society that resulted. Relatedly, there were few towns, land was generally poor and so farms were huge and isolated, and educational opportunities ranged from absent to limited.

12. As Schreiner pointed out in her 1898 'A Returned South African' essay on 'The Boer Woman', which later posthumously appeared in Olive Schreiner, Thoughts on South Africa (London: T. Fisher Unwin, 1923). For a critical discussion of the neglect of frontier and other women in South African historiography, see Helen Bradford, 'Women, Gender and Colonialism: Rethinking the History of the British Cape Colony and its Frontier Zones, c.1806-1970', Journal of African History 37 (1996), pp. 351-70.

13. We describe this as 'ethnic/racial' over the time-period of Schreiner's youth and younger womanhood, up to approximately 1910, because racial categorisation did not supplant the importance of ethnic groupings and their very different relationships at local levels with white colonialists until after Union of the settler states and its rapid introduction of racially-retrograde legislation.

14. See Karel Schoeman, Olive Schreiner: A Woman in South Africa 1855-1881 (Johannesburg: Jonathan Ball Publishers, 1989).

15. Olive Schreiner, The Story of an African Farm.

16. Olive Schreiner to Havelock Ellis, 15 April 1890, <http://www.oliveschreiner.org/vre?view=collections\& colid $=137 \&$ letterid $=396>$.

17. These were linked and intended for later publication in book form as 'Stray Thoughts on South Africa', although a dispute with the intended US publisher and then the South African War (1899-1902) prevented this. With some related essays, they were posthumously published as Olive Schreiner, Thoughts on South Africa.

18. Olive Schreiner to W. T. Stead, January-March 1889, <http.www.oliveschreiner.org/vre/T120 (M722): W.T. Stead Papers/1- pages 39-41>.

19. Olive Schreiner, Thoughts on South Africa, pp. 27-30.

20. Schreiner's reasons for leaving South Africa in 1913 were complicated and include her deteriorating heart condition and search for better medical treatment, her anger at racially retrograde changes occurring in its political life and the near-breakdown of her marriage over her suspicion that her husband 'Cron' Cronwright-Schreiner was involved with another woman.

21. For a detailed discussion of issues around race concerning Schreiner's letter writing practices, see Liz Stanley and Helen Dampier, "I Trust that our Brief Acquaintance May Ripen into Sincere Friendship": Networks Across The Race Divide In South Africa In Conceptualising Olive Schreiner's Letters, 1890-1920', OSLP Working Papers on Letters, Letterness \& Epistolary Networks, No. 2 (2010), $<$ http://www.oliveschreinerletters.ed.ac.uk/GiantRaceArticlePDF.pdf > .

22. For useful overviews, see Stanley Trapido, 'South Africa and the Historians', African Affairs 71 (1972), pp. 434-58 and Wessel Visser, 'Trends in South African Historiography and the Present State of Historical Research', Unpublished paper presented at the Nordic Africa Institute, Uppsala, Sweden, 23 September 2004. Regarding well-known examples, see Sarah Gertrude Millin, General Smuts (London: Faber \& Faber, 1935); Eric A. Walker, W. P. Schreiner: A South African (Oxford: Oxford University Press, 1937); Lewsen, John X. Merriman; Phyllis Lewsen, 'Olive Schreiner's Political Theories and Pamphlets' in Cherry Clayton (ed.), Olive Schreiner (Johannesburg: McGraw-Hill, 1983), pp. 212-20.

23. Martin Legassick, 'Legislation, Ideology and Economy in Post-1948 South Africa', Journal of Southern African Studies 1 (1974), pp. 5-35; Frederick Johnstone, Class, Race and Gold. A Study of Class Relations and Racial Discrimination in South Africa (London: Routledge \& Keegan Paul, 1976); Shula Marks and Anthony Atmore (eds), Economy and Society in Pre-Industrial South Africa (London: Longman, 1980); Shula Marks and Stanley Trapido (eds), The Politics of Race, Class and Nationalism in Twentieth-Century South Africa (Harlow: Longman, 1987); Harold Wolpe, Race, Class and the Apartheid State (London: Currey, 1988).

24. Liz Stanley, Mourning Becomes ... Post/Memory, Commemoration \& the Concentration Camps of the South African War (Manchester: Manchester University Press, 2006); Liz Stanley and Helen Dampier, 'The Number of the South African War (1899-1902) Concentration Camp Dead: Standard Stories, Superior Stories and a Forgotten Proto-Nationalist Research Investigation,' Sociological Research Online 14:5 (2009), <www.socresonline.org.uk/14/5/13.html>. 
25. Regarding the intertwining of women's and black history, see Nomboniso Gasa (ed.), Women In South African History (Cape Town: Human Sciences Research Council, 2007).

26. At Schreiner's death, around 20,000 of her letters appear to have existed; now there are c.4,800 extant, with large numbers having been obtained and then destroyed by her then estranged husband Cronwright-Schreiner after preparing The Life of Olive Schreiner and The Letters of Olive Schreiner. See S. C. Cronwright-Schreiner, The Letters of Olive Schreiner (London: T. Fisher Unwin, 1924) and S. C. Cronwright-Schreiner, The Life of Olive Schreiner (London: T. Fisher Unwin, 1924). We are of course aware that the destructions mark what remains; this in largely unknowable ways, except that the evidence suggests they were of entire correspondences rather than targeted at censoring particular letters.

27. For Schreiner's relevant letters on such topics, see $<\mathrm{http}: / / \mathrm{www}$.oliveschreiner.org/vre?page $=$ nativequestion $>$ and <http://www.oliveschreiner.org/vre?page=raceandlabour $>$. See also Liz Stanley and Helen Dampier, "She Wrote Peter Halket": Fictive and Factive Devices in Olive Schreiner's Letters and Trooper Peter Halket of Mashonaland' in David Robinson et al. (eds), Narratives and Fiction (Huddersfield: University of Huddersfield Press, 2008), pp. 85-102; Liz Stanley and Helen Dampier, "Men Selling their Souls \& the Future - and Fate Watching Them": Olive Schreiner on Union', Quarterly Bulletin of the National Library of South Africa 64 (2010), pp. 121-36; Stanley and Dampier, 'I Trust that our Brief Acquaintance may Ripen into Sincere Friendship'; Liz Stanley and Helen Dampier, “"The Tone Of Things There I Fear Rather Hopeless" - Olive Schreiner, Will Schreiner, Charles Dilke and the 1909 Protest Against The Draft South Africa Act', Quarterly Bulletin of the National Library of South Africa (2012, in progress).

28. For Schreiner's letters on these and also topics, see $<$ http://www.oliveschreiner.org/vre?page=bytopic $>$.

29. The convention among many scholars of epistolarity is that 'the letter' forms a distinct if complex genre around absence, interiority and self-making. However, Schreiner's letters after 1889 are concerned with the material world and the 'other' of her correspondents and consequently 'the familiar' and 'the personal' are reconfigured within and by them.

30. See Ken Plummer, Documents of Life 2 (London: Sage, 2001); Brian Roberts, Biographical Research (Buckingham: Open University Press, 2001) and for a counter-view of letters, Liz Stanley, 'The Epistolarium: On Theorising Letters and Correspondences', Auto/Biography 12 (2004), pp. 216-50.

31. See Stanley, 'Shadows Lying Across Her Pages'; Stanley, 'The Epistolarium'; Liz Stanley, 'On Small and Big Stories of the Quotidian: The Commonplace and the Extraordinary In Narrative Inquiry' in David Robinson et al. (eds), Narratives and Everyday Life (Huddersfield: University of Huddersfield Press, 2010), pp. 1-24; Liz Stanley, 'Letters, The Epistolary Gift, The Editorial Thirty-Party, Counter-Epistolaria: Rethinking The Epistolarium', Life Writing 8 (2011) pp. 135-52; Stanley and Dampier, 'She wrote Peter Halket'; Liz Stanley and Helen Dampier, 'Towards the Epistolarium: Issues In Researching and Publishing the Olive Schreiner Letters', African Research \& Documentation 113 (2010), pp. 27-32; Stanley and Dampier, 'Men Selling their Souls \& the Future - and Fate Watching Them'; Stanley and Dampier, 'I Trust that our Brief Acquaintance may Ripen into Sincere Friendship'; Liz Stanley, Helen Dampier and Andrea Salter, 'Olive Schreiner Globalising Social Inquiry', Sociological Review 58 (2010), pp. 657-80; Liz Stanley and Andrea Salter "'Her Letters Cut are Generally Nothing of Interest": The Heterotopic Persona of Olive Schreiner and The Alterity-Persona Of Cronwright-Schreiner', English in Africa 36 (2009), pp. 7-30.

32. For examples see Michael Warner, The Letters of the Republic (Cambridge: Harvard University Press, 1990); James How, Epistolary Spaces (London: Ashgate, 2003); Caroline Bland and Maire Cross (eds), Gender and Politics in the Age of Letter-Writing 1750-2000 (London: Ashgate, 2004) and Emma Rothschild, The Inner Life of Empires (Princeton: Princeton University Press, 2011).

33. Walker, W. P. Schreiner; see also Guy Willoughby, "CColoured and Native British Subjects of South Africa" and the Act of Union in 1909', Quarterly Bulletin of the National Library of South Africa 64 (2010), pp. 108-16. Will Schreiner's political career also figures prominently in biographies and autobiographies of his contemporaries. See Millin, General Smuts; F. S. Crafford, Jan Smuts: A Biography (Cape Town: Timmins for Allen \& Unwin, 1946); James Rose Innes, James Rose Innes: Chief Justice of South Africa Autobiography (London: Oxford University Press, 1949); Lewsen, John X. Merriman. The major archival collections are: W. P. Schreiner Collection, National Library of South Africa, Cape Town; W. P. Schreiner Collection, University of Cape Town.

34. As this suggests, over time Will Schreiner developed many close links with black, coloured and Indian politicians, journalists and other leading figures; see Stanley and Dampier, 'I Trust that our Brief Acquaintance may Ripen into Sincere Friendship'. There are close parallels here with Olive Schreiner herself and also their other siblings Ettie Stakesby Lewis and Theo Schreiner, with the political base of the latter being Ettie's leading and Theo's supporting role in a Christian fundamentalist temperance context. 
35. Olive Schreiner, Thoughts on South Africa; Olive Schreiner, The Political Situation (London: Unwin, 1896); Olive Schreiner, Trooper Peter Halket of Mashonaland (London: Unwin, 1897), Olive Schreiner, An English South African's View of the Situation (London: Hodder and Stoughton, 1899); Olive Schreiner, Closer Union (London: Fifield, 1909); Olive Schreiner, Woman and Labour (London: Unwin, 1911).

36. The handful of South African exceptions in this time period include feminist links between Schreiner and her friends Mary Sauer and Jessie Rose Innes, who were married to prominent Cape Liberal politicians; Marie Koopmans De Wet, who presided over a salon of the Cape Afrikaner elite and Schreiner's older sister Ettie Stakesby Lewis, who was a major figure in the South African Christian Temperance movement.

37. Walker, W. P. Schreiner, p. 139.

38. Walker, W. P. Schreiner, p. 47.

39. Walker, W. P. Schreiner, pp. 111-12.

40. Walker, W. P. Schreiner, p. 139.

41. Walker, W. P. Schreiner, p. 139.

42. See exchanges of letters over this period in the W. P. Schreiner Collection, National Library of South Africa, Cape Town.

43. This raises the more general historiographical point that often the researcher knows with reasonable certainty from circumstantial evidence that something is so, but lacks the direct evidence that would demonstrate this with incontrovertible certainty.

44. Walker, W. P. Schreiner, pp. 177-8.

45. See for example Olive Schreiner to Will Schreiner, 14 September 1899, <http://www.oliveschreiner.org/ vre?view $=$ collections \& colid $=91 \&$ letterid $=66>$ and 24 September 1899, <http://www.oliveschreiner. $\mathrm{org} / \mathrm{vre}$ ?view $=$ collections $\&$ colid $=91 \&$ letterid $=70>$.

46. Walker, W. P. Schreiner, pp. 190-91.

47. Walker, W. P. Schreiner, p. 216.

48. Walker, W. P. Schreiner, p. 306.

49. Olive Schreiner to Will Schreiner, 14 September 1899, <http://oliveschreiner.org/vre?view= collections\&colid $=91 \&$ letterid $=66>$.

50. Olive Schreiner to Will Schreiner, 20 June 1900, <http://www.oliveschreiner.org/vre?view=collections\& archiveid $=33 \&$ colid $=92 \&$ letterid $=35 \&$ arrangeby $=$ reciascdateasc $>$; Walker, W. P. Schreiner, p. 235.

51. Walker, W. P. Schreiner, p. 351.

52. Walker, W. P. Schreiner, pp. 349-50.

53. Olive Schreiner to Betty Molteno, 18 September 1897, <http://www.oliveschreiner.org/vre? view $=$ collections \& colid $=89 \&$ letterid $=17>$.

54. Such evidence might have been provided by Will Schreiner's letters to his sister, but these too were routinely destroyed by her.

55. Phyllis Lewson, Selections From the Merriman Correspondence 1890-1924 (Cape Town: Van Riebeeck, 1960-1969); Lewsen, John X. Merriman.

56. As Schreiner wrote to Merriman, 'Under our wretched party system of government, it seems all persons \& no principles'. Olive Schreiner to John X. Merriman, 2 August 1907, <http://www. oliveschreiner.org/vre?view $=$ collections $\&$ colid $=51 \&$ letterid $=27>$.

57. Olive Schreiner to John X. Merriman, 25 May 1896, <http://www.oliveschreiner.org/vre?view= collections\&colid $=51 \&$ letterid $=2>$.

58. Olive Schreiner to Will Schreiner, 9 April 1909, <http://www.oliveschreiner.org/vre?view=collections\& archiveid $=33 \&$ colid $=101 \&$ letterid $=20 \&$ arrangeby $=$ reciascdateasc $>$.

59. Olive Schreiner to John X. Merriman, June 1913, < http://www.oliveschreiner.org/vre?view=collections\& archiveid $=28 \&$ colid $=51 \&$ letterid $=42 \&$ arrangeby $=$ reciascdateasc $>$.

60. Schreiner, Trooper Peter Halket of Mashonaland.

61. His biographer, Phyllis Lewsen, states that 'Olive Schreiner's . . Peter Halket of Mashonaland, impressed him deeply. Its polemical attacks on Rhodes, which Merriman found brave and pertinent, caused a vicious campaign against her ... a letter from Merriman in late 1896 moved her profoundly and began a remarkable though intermittent correspondence'. (Lewsen, John X. Merriman, pp. 183-4). Unfortunately Schreiner's response to his initial letter cannot be traced in the Merriman collection (Merriman Collection, National Library of South Africa, Cape Town).

62. Olive Schreiner to John X. Merriman, 3 April 1897, <http://www.oliveschreiner.org/vre?view= collections \&archiveid $=28 \&$ colid $=51 \&$ letterid $=9 \&$ arrangeby $=$ reciascdateasc $>$.

63. Olive Schreiner to Will Schreiner, 10 May 1908, <http://www.oliveschreiner.org/vre?view= collections\&colid $=100 \&$ letterid $=29>$.

64. Olive Schreiner to John X. Merriman, Wednesday 1906, <http://www.oliveschreiner.org/vre?view= collections \& colid $=51 \&$ letterid $=25>$. 
65. Olive Schreiner to John X. Merriman, Wednesday 1906, <http://www.oliveschreiner.org/vre?view= collections\&colid $=51 \&$ letterid $=25>$.

66. Olive Schreiner, Woman and Labour (London: Unwin, 1911).

67. Olive Schreiner to Ettie Stakesby-Lewis, 5 May 1911, <http://www.oliveschreiner.org/vre?view= collections\&colid $=77 \&$ letterid $=118>$.

68. Schreiner, An English South African's View of the Situation.

69. Olive Schreiner to Jan Hofmeyr, 3 June 1899, <http://www.oliveschreiner.org/vre?view=collections\& colid $=141 \&$ letterid $=15>$

70. Jan Hofmeyr notes, written on Olive Schreiner to Jan Hofmeyr, 3 June 1899, <http://www. oliveschreiner.org/vre?view $=$ collections\&colid $=141 \&$ letterid $=15>$.

71. Stanley, 'The Epistolarium'; Stanley, 'Letters, The Epistolary Gift, The Editorial Thirty-Party, CounterEpistolaria'.

72. J. L. Austin, How To Do Things With Words (Cambridge: Clarendon Press, 1962).

73. Olive Schreiner to Mrs Goosen, 14 May 1909, <http://www.oliveschreiner.org/vre?view=collections\& colid $=42 \&$ letterid $=1>$.

74. Olive Schreiner to F. S. Malan, 16 October 1913, <http://www.oliveschreiner.org/vre?view= collections \& colid $=44 \&$ letterid $=9>$.

75. See for example, Schreiner's letters to Julia Solly and to Minnie Murray, $<$ http://www.oliveschreiner.org $>$.

76. Olive Schreiner to Will Schreiner, 30 April 1899, <http://www.oliveschreiner.org/vre?view= collections\&colid $=91 \&$ letterid $=23>$.

77. Adele Chapin was married to the US consular agent in Johannesburg, Robert Chapin.

78. A lawyer by training, Smuts was legal advisor to Cecil Rhodes from 1895, but after the Jameson Raid became State Secretary in the Transvaal. He served as a Boer general during the South African War, and was later a key force in South African politics, serving twice as Prime Minister. An international statesman, he was instrumental in setting up the League of Nations. See Millin, General Smuts; F. S. Crafford, Jan Smuts: A Biography (Cape Town: Timmins for Allen \& Unwin, 1946).

79. Olive Schreiner to Jan Smuts, n.d. 1899, <http://www.oliveschreiner.org/vre?view=collections\&colid= 70\&letterid=7>. In Milner's case, it certainly did. In a 28 March 1899 letter to Adele Chapin, he commented 'Do you see much of Olive Schreiner? She is, to me, the most interesting of S. African humans, and it is bad luck she never comes - perhaps can never come - to this part of the world ...' Sir Alfred Milner, The Milner Papers, vol. 1, South Africa 1897-1899, Cecil Headlam (ed.) (London: Cassell \& Company, 1931), p. 336.

80. Olive Schreiner to Will Schreiner, 4 June 1899, <http://www.oliveschreiner.org/vre?view=collections \& archiveid $=33 \&$ colid $=91 \&$ letterid $=37 \&$ arrangeby $=$ reciascdateasc $>$.

81. Abrams, 'The Unseamed Picture', pp. 64-41.

82. Rather than as a novelist, as she is mainly remembered today, including in South Africa.

83. For Schreiner's involvements with black leaders and politicians and issues in researching this, see Stanley and Dampier, 'I Trust that our Brief Acquaintance May Ripen into Sincere Friendship'.

84. An interesting example is found in a Schreiner letter to her close friend Mary Sauer: 'It's rather interesting that after the people's congress meeting two old fashioned Africanders, Doppers!! came to me, \& asked whether I wasn't going to the Bond congress. I said no, I wasn't a Bond's man, \& no women were admitted. They said solemnly, that it didn't matter, that I ought to go to parliament!!!! This was to me very interesting as showing how even the hardshell old Dopper can modify his view, the moment he sees a practical reason for it!!' Olive Schreiner to Mary Sauer, Sunday 1903; $<$ http://www.oliveschreiner.org/vre?view=collections \&colid=62\&letterid=133>). The Doppers were the most narrow and puritanical of the Dutch Reform Church schisms in South Africa.

85. See Leonore Davidoff, “"Regarding Some "Old Husbands” Tales”: Public and Private in Feminist History', in Leonore Davidoff, Worlds Between: Historical Perspectives On Gender and Class (Oxford: Polity Press, 1995), pp. 227-76. And also Jeff Weintraub, 'The Theory and Politics of the Public/Private Distinction' in Jeff Weintraub and Krishan Kumar (eds), Public and Private in Theory and Practice (Chicago: University of Chicago Press, 1997), pp. 119-224.

86. Peggy Watson, 'Rethinking Transition: Globalism, Gender and Class' in Joan Scott and Debra Keates (eds), Going Public: Feminism and the Shifting Boundaries of the Private Sphere (Urbana: Illinois University Press, 2004), pp. 282-304.

87. Liz Stanley, Helen Dampier and Andrea Salter, 'The Epistolary Pact and Letterness in the Schreiner Epistolarium', a/b: Auto/Biography Studies (2012, in press).

88. Kathleen Canning, Gender History in Practice (Ithaca: Cornell University Press, 2006), p. 61. 